\title{
Editorial
}

\section{A Vision of the Future for JIEM: News and New Editor-in-Chief}

\author{
Juan A. Marin-Garcia ${ }^{1}$ iD, Irene Trullas $^{2}$ (iD \\ ${ }^{1}$ JIEM Editor-in-Chief \& Professor at the Universitat Politécnica de Valencia (Spain) \\ ${ }^{2}$ OmniaScience (Spain) \\ jamarin@jiem.org, irene.trullas@,omniascience.com
}

\section{Introduction}

The editorial of the third issue of 2016 (Fernandez, 2016) reviewed nine years of work by the editorial team, from the date the journal was founded, until the present day. In this regard, it announced the need for changes in the journal and introduced me as the new Editor-in-Chief of the journal. As the new editor and this being the first editorial written by the new team, first of all, we would like to express our appreciation for the offer and the responsibility placed in us by the founders (i.e., Fernandez et al., 2008) and the OmniaScience publishing company. In this manner, we would like to introduce the journal, the new team and the new developments in its management to the scientific community.

\section{New editorial team and scope of the journal}

I am joined by a group of researchers from the Universitat Politècnica de Valencia (Josefa Mula, Carlos Andres-Romano and Pilar I. Vidal-Carreras), and together, we will be responsible for the new scientific management of the journal. For this purpose, and in light of the orientation of most of the articles received, we have decided to center the focus and scope of the journal on Operations Management. This is an area in which a great deal of progress can be made on the frontier of knowledge between management/business administration (in its operations management aspects) and industrial engineering, in a simultaneous and reinforced manner, with contributions that have a scientific impact and which are useful for practitioners (Elsayed, 1999; Gallwey, 1992; Marin-Garcia, 2011; Marin-Garcia, Garcia-Sabater, 
Miralles, \& Rodriguez Villalobos, 2008; Marin-Garcia, Garcia-Sabater, Perello-Marin, \& Canos-Daros, 2009; Marin-Garcia \& Lloret, 2011; Salvendy, 2001; Vallhonrat Bou, 2010).

As seen on the JIEM website (http://www.jiem.org/index.php/jiem/about/editorialPolicies\#focusAndScope), the scope of the journal is focused on Operations Management, covering five large dimensions:

1. Production Planning - Scheduling - Inventory

2. Logistics - Supply Chain

3. Quality Management

4. Operations Management

5. Operational Research

This means that the main topics of interest are related, but not limited, to: Supply Chain Management, Green Supply Chains, Logistics in general, Lean Manufacturing, Operations Improvement, Innovation Management in Operations, Operations in Service Industry, Operational Research, Total Quality Management, Total Productive Maintenance, how to manage the workforce in Operations and how to improve Operation Management competencies.

We therefore encourage authors in any of these disciplines to submit their scientific contributions related to Operations Management to JIEM.

We would like to take a moment to remind everyone that JIEM has been indexed in Scopus since 2010, and in ESCI (Thomson) since 2015, among many other indexes and bibliometric indicators (JIEM, 2017).

\section{Plagiarism and originality}

Another novel aspect this year that is here to stay at JIEM is the active proposal to combat plagiarism and self-plagiarism. In this sense, and as until now, authors and co-authors are recommended to be precise when citing already published documents (OmniaScience, 2015). The experience of OmniaScience has enabled us to see that this does not always occur, and so on an editorial level, OmniaScience has decided to incorporate an active plagiarism control system in all of its journals. Plagiarism can take on many shapes and forms, from authors who use their own previously published articles for republication, to authors who take other authors' texts and include them in their own documents, intentionally or not, without the required citation, thus making the texts appear to be their own, i.e., improperly assuming authorship of them. 
On the one hand, to minimize the reception and on the other hand, and most importantly, to prevent the publication of plagiarized, self-plagiarized or partially plagiarized articles in OmniaScience journals, in particular in JIEM, the journal will use specialized software to check articles received after March 2017.

Crossref Similarity Check (2017) is a computer program that will help journal editors verify the originality of the documents received. Crosscheck powered by Ithenticate is a program containing the most extensive database for comparisons available today, which is why it was chosen to perform this task. It is known within the scientific community as Turnitin by iParadigms.

This program includes the published works of more than 200 Crossref members who contribute the complete text of articles to the database, as well as the chapters of scientific books, thus resulting in a collection of more than 50 million documents. This database does not contain everything published, since the scientific production of members not affiliated with Crossref may not be included; it does, however, contain a large share of the published works. Accordingly, the entire content of JIEM is added to the aforementioned database, permitting other publishers to detect attempts to plagiarize JIEM documents, thus protecting JIEM authors from most plagiarism attempts.

In this manner, JIEM readers can be much more sure that the journal publications are original and have not been previously published, which provides added value to the journal authors. At the same time, they will be better protected against possible future attempts at plagiarism.

\section{Payment per review}

One of the most important jobs of a scientific journal is the scientific review conducted by researchers. In most journals, both closed and open access, this work is unpaid. As a result, among other drawbacks, the editors-in-chief find it extremely difficult to locate reviewers willing to do this job for free. On many occasions, the search process can take as long as 6 months. Once the appropriate reviewer has been found and has accepted the work, we must wait until the review has been finished, keeping in mind that it is not this person's main job and it is unpaid. This results in long delays and can result in despair on the part of authors who are waiting and the editors who are managing the work. On many occasions, the only compensation reviewers get is a certificate they can add to their curriculum vitae and present for accreditation as part of their university work.

At JIEM, with the incorporation of the Payment per review system, part of the publication income from authors or research institutions is used to pay reviewers for this work, as long as the reviews are of good quality and delivered by the stipulated deadline. We hope this speeds up the process and increases the 
quality of the article reviews, thus increasing the satisfaction of the authors who publish in JIEM and indirectly benefiting the entire scientific community.

\section{Renewal of the reviewers and the editorial board}

Over the course of this year, taking advantage of the incorporation of the Payment per review system, we plan to renew the journal's board of reviewers. To be a JIEM reviewer, fill out the registration form (https://goo.gl/forms/eiGWaRN70dzVvgri1), which will ask you for basic identification information, such as your email, ORCID, whether you hold a PhD, information about your scientific production and access to the main consultation databases, as well as your areas of knowledge. Once your proposal has been received, the editor-in-chief of the journal will evaluate your candidacy and determine whether you will go on to form part of the new review board of the journal. If so, you will be registered in the system and be sent an email confirming your entry. When you are assigned a review, you will be asked to complete it within a pre-established period of time ( 2 weeks) and with an appropriate level of quality. Reviewers who complete their work according to these premises will be compensated with $€ 20$, which will accumulate in their account. Once the total accumulated amount reaches $€ 100$, OmniaScience will contact the reviewer to initiate the payment process for this amount.

Finally, a process has begun to renew the journal's scientific board, with the intention of including the main scientists in the area in order to strengthen it and make it one of the best in the area of Operations Management.

\section{References}

Borenstein, M., Hedges, L.V., Higgins, J.P T., \& Rothstein, H.R. (2009). Introduction to meta-analysis. UK: John Wiley \& Sons. https://doi.org/10.1002/9780470743386

Burke-Smalley, L.A. (2014). Evidence-based management education. Journal of Management Education, 38(5), 764-767. https://doi.org/10.1177/1052562914529418

Cascio, W.F. (2007). Evidence-based management and the marketplace for ideas. Academy of management Journal, 50(5), 1009-1012. https://doi.org/10.5465/AMJ.2007.27151942

Cooper, H., Hedges, L., \& Valentine, J.C. (2009). The handbook of research synthesis and meta-analysis (2nd ed.). New York: Russell SAGE Foundation. 
Elsayed, E.A. (1999). Industrial engineering education: A prospective. European Journal of Engineering Education, 24(4), 415-421. https://doi.org/10.1080/03043799908923576

Gallwey, T. J. (1992). Europe needs industrial engineering degrees in order to enhance its competitiveness. European Journal of Engineering Education, 17(1), 51-57. https://doi.org/10.1080/03043799208923155

Gerber, A.S., \& Malhotra, N. (2008). Publication bias in empirical sociological research: Do arbitrary significance levels distort published results? Sociological Methods \& Research, 37(1), 3-30. https://doi.org/10.1177/0049124108318973

Harrison, J.S., Banks, G.C., Pollack, J.M., O'Boyle, E.H., \& Short, J. (2014). Publication bias in strategic management research. Journal of Management, Advanced Online.

JIEM (2017). Indexing of JIEM. Available at: http://www.jiem.org/index.php/iiem/pages/view/index. Accessed: March 2017.

Lawler, E.E. (2007). Why hr practices are not evidence-based. Academy of management Journal, 50(5), 10331036. https://doi.org/10.5465/AMJ.2007.27155013

Marin-Garcia, J.A. (2011). ¿Dónde se publican artículos de investigación docente relacionados con asignaturas de ingeniería industrial? (where are published research articles related to university teaching of industrial engineering?). WPOM-Working Papers on Operations Management, 2(1), 1-6. https://doi.org/10.4995/wpom.v2i1.784

Marin-Garcia, J.A. (2015). Publishing in two phases for focused research by means of "research collaborations". WPOM-Working Papers on Operations Management, 6(2), $76-80$. http://dx.doi.org/10.4995/wpom.v6i2.4459

Marin-Garcia, J.A., Garcia-Sabater, J. ., Miralles, C., \& Rodríguez Villalobos, A. (2008). Profile and competences of spanish industrial engineers in the european higher education area (ehea). Journal of Industrial Engineering and Management, 1(2), 269-284. https://doi.org/10.3926/jiem.2008.v1n2.p269-284

Marin-Garcia, J.A., Garcia-Sabater, J.P., Perello-Marin, M.R., \& Canos-Daros, L. (2009). Proposal of skills for the bachelor degree of industrial engineering in the context of the new curriculum. Intangible Capital, 5(4), 387-406. https://doi.org/10.3926/ic.2009.v5n4.p387-406

Marin-Garcia, J.A., \& Lloret, J. (2011). Industrial engineering higher education in the european area (ehea). Journal of Industrial Engineering and Management, 4(1), 1-12. https://doi.org/10.3926/jiem.2011.v4n1.p1-12

Morrell, K., \& Learmonth, M. (2015). Against evidence-based management, for management learning. Academy of Management Learning \& Education, 14(4), 520-533. https://doi.org/10.5465/amle.2014.0346 
OmniaScience (2015). Publication Ethics/Guidelines on Research. Available at: http://www.omniascience.com/? page id=3911\&lang=en. Accessed: March 2017.

Paauwe, J. (2009). Hrm and performance: Achievements, methodological issues and prospects. Journal of Management Studies, 46(1), 129-142. https://doi.org/10.1111/j.1467-6486.2008.00809.x

Pfeffer, J., \& Sutton, R.I. (2006). Evidence-based management. Harvard Business Review, 84(1), 62.

Pigott, T.D. (2012). Advances in meta-analysis. New York: Springer. https://doi.org/10.1007/978-1-4614-2278-5

Polanin, J.R., Tanner-Smith, E.E., \& Hennessy, E.A. (2016). Estimating the difference between published and unpublished effect sizes: A meta-review. Review of Educational Research, 86(1), 207-236. https://doi.org/10.3102/0034654315582067

Salvendy, G. (2001). Handbook of industrial engineering. Technology and operations management. New York: John Wiley \&Sons. https://doi.org/10.1002/9780470172339

Shadish, W., Cook, T., \& Campbell, D.T. (2002). Experimental and quasi-experimental designs for generalized causal inference. Boston New York: Houghton Mifflin Company.

Similarity Check (2017). Crossref. Similarity Check. Available at: https://www.crossref.org/services/similarity-check/. Accessed: March 2017.

Thompson, M. (2007). Innovation in work practices: A practice perspective. The International Journal of Human Resource Management, 18(7), 1298-1317. https://doi.org/10.1080/09585190701393855

Thyer, B.A. (2004). What is evidence-based practice? Brief Treatment and Crisis Intervention, 4(2), 167. https://doi.org/10.1093/brief-treatment/mhh013

Vallhonrat bou, J.M. (2010). Manual de ingeniería y organización industrial. H.B. Maynard. Barcelona: Editorial Reverté, S.A.

Wall, T.D., \& Wood, S.J. (2005). The romance of human resource management and business performance, and the case for big science. Human relations, 58(4), 429, 462.

https://doi.org/10.1177/0018726705055032

Journal of Industrial Engineering and Management, 2017 (www.jiem.org)

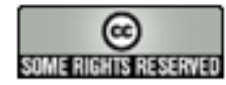

Article's contents are provided on an Attribution-Non Commercial 3.0 Creative commons license. Readers are allowed to copy, distribute and communicate article's contents, provided the author's and Journal of Industrial Engineering and Management's names are included. It must not be used for commercial purposes. To see the complete license contents, please visit http://creativecommons.org/licenses/by-nc/3.0/. 